\title{
FIRST RECORD OF Uroderma magnirostrum DAVIS, 1968 (CHIROPTERA: PHYLLOSTOMIDAE) IN THE NORTHEASTERN ATLANTIC FOREST OF BRAZIL
}

\author{
Hannah Nunes ${ }^{1,2 *}$, Patrício Adriano da Rocha ${ }^{1,2}$, Jeanneson Sales ${ }^{1}$, \\ Fabiana Lopes Rocha ${ }^{1,3}$ \& Pedro Cordeiro-Estrela ${ }^{1,2}$
}

\begin{abstract}
${ }^{1}$ Universidade Federal da Paraíba Campus I, Departamento de Sistemática e Ecologia, Laboratório de Mamíferos, Cidade Jardim Universitário, s/n, Castelo Branco, CEP 58051-900, João Pessoa, PB, Brazil.

2 Universidade Federal da Paraíba Campus I, Departamento de Sistemática e Ecologia, Programa de Pós-Graduação em Ciências Biológicas, Cidade Jardim Universitário, s/n, Castelo Branco, CEP 58051-900, João Pessoa, PB, Brazil.

${ }^{3}$ Universidade Federal da Paraíba Campus IV, Departamento de Engenharia e Meio Ambiente, Programa de PósGraduação em Ecologia e Monitoramento Ambiental, Rua da Mangueira, s/n, CEP 58297-000, Rio Tinto, PB, Brazil.

E-mails: hannahlarissa@gmail.com (*corresponding author); parocha2@yahoo.com.br; jeannesonsilva@gmail.com; lopesrocha.fabiana@gmail.com; pedrocometa@gmail.com
\end{abstract}

\begin{abstract}
Uroderma magnirostrum Davis, 1968 (Chiroptera: Phyllostomidae) is distributed from Mexico to the southeastern coast of Brazil. Here we report the first record in the Northeastern Atlantic Forest of Brazil, based on the capture of one adult female in an urban forest fragment in the state of Paraíba. Morphological features and morphometric data of our specimen fall within the range described previously for the species. The present record extends the known species distribution $c a .450 \mathrm{~km}$ to the Northeast from the closest locality in Sergipe state. Uroderma magnirostrum is currently recorded in 23 localities from 15 states in Brazil, in the Amazonia, Cerrado, Caatinga and Atlantic Forest biomes. Additionally, our record updated the bat list of the Paraíba state to 62 bat species.
\end{abstract}

Keywords: geographical distribution; Paraíba state; Stenodermatinae; urban areas

The genus Uroderma Peters, 1865 currently includes five species of medium-sized frugivorous bats (sensu Mantilla-Meluk 2014): U. bilobatum Peters, 1866; U. magnirostrum Davis, 1968; U. convexum Lyon, 1902; U. bakeri Mantilla-Meluk, 2014, and U. davisi Baker \& Mc-Daniel, 1972. The brown tent-making bat $U$. magnirostrum (Chiroptera: Phyllostomidae) is known to occur from Mexico and Central America to the southeastern coast of Brazil (Gardner 2007). It is distributed within all major Brazilian biomes, in Amazon (Bernard \& Fenton 2002, Bernard et al. 2011), Cerrado (Pine et al. 1970, Silva \& Anacleto 2011),
Caatinga (Mares et al. 1981, Rocha et al. 2011), and Atlantic Forest (Nogueira et al. 2003, Oprea et al. 2009; Table 1 and Figure 1). This species is often associated with humid lowland areas and seems to have some level of tolerance to environmental changes due to its occurrence in anthropogenic landscapes, such as urban areas, pastures, orchards, and croplands (Handley 1976, Nunes et al. 2017).

Here we report the first record of $U$. magnirostrum for the northeastern Atlantic Forest of Brazil, more precisely in the Pernambuco Endemism Center (sensu Silva \& Casteleti 2003), 
Table 1. Locality records of Uroderma magnirostrum (Chiroptera: Phyllostomidae) in Brazil. Asterisk indicates the new record in the state of Paraíba, Northeast of Brazil. The code numbers correspond to the records indicated in the Figure 1.

\begin{tabular}{|c|c|c|c|c|c|}
\hline \multirow{2}{*}{$\begin{array}{c}\text { Code } \\
\text { number }\end{array}$} & \multicolumn{2}{|c|}{ Coordinates } & \multirow[b]{2}{*}{ State } & \multirow[b]{2}{*}{ Locality } & \multirow[b]{2}{*}{ Reference } \\
\hline & Latitude & Longitude & & & \\
\hline 1 & $07^{\circ} 36^{\prime} 36^{\prime \prime} \mathrm{S}$ & $72^{\circ} 39^{\prime} 00^{\prime \prime} \mathrm{W}$ & Acre & Cruzeiro do Sul & Taddei et al. (1990) \\
\hline 2 & $08^{\circ} 48^{\prime} 36^{\prime \prime S}$ & $72^{\circ} 56^{\prime} 24^{\prime \prime} \mathrm{W}$ & Acre & $\begin{array}{l}\text { Parque Nacional da Serra do } \\
\text { Divisor, Marechal } \\
\text { Taumaturgo }\end{array}$ & Nogueira et al. (2003) \\
\hline 3 & $08^{\circ} 48^{\prime} 36^{\prime \prime} \mathrm{S}$ & $63^{\circ} 56^{\prime} 24^{\prime \prime} \mathrm{W}$ & Rondônia & Porto Velho & Tavares et al. (2017) \\
\hline 4 & $03^{\circ} 22^{\prime} 48^{\prime \prime} \mathrm{N}$ & $61^{\circ} 40^{\prime} 48^{\prime \prime} \mathrm{W}$ & Roraima & Ilha de Maracá & Taddei \& Reis (1980) \\
\hline 5 & $03^{\circ} 1^{\prime} 48^{\prime \prime S}$ & $60^{\circ} 00^{\prime} 00^{\prime \prime} \mathrm{W}$ & Amazonas & $\begin{array}{l}\text { Colônia de Santo Antonio, } \\
\text { Manaus }\end{array}$ & Reis \& Peracchi (1987) \\
\hline 6 & $03^{\circ} 49^{\prime} 48^{\prime \prime S}$ & $56^{\circ} 15^{\prime} 00^{\prime \prime} \mathrm{W}$ & Pará & $\begin{array}{l}\text { Parque Nacional da } \\
\text { Amazônia }\end{array}$ & Reis \& Schubart (1979) \\
\hline 7 & $02^{\circ} 30^{\prime} 00^{\prime \prime S}$ & $55^{\circ} 57^{\prime} 00^{\prime \prime} \mathrm{W}$ & Pará & Alter do Chão & Bernard \& Fenton (2002) \\
\hline 8 & $03^{\circ} 30^{\prime} 00^{\prime \prime S}$ & $52^{\circ} 23^{\prime} 60^{\prime \prime} \mathrm{W}$ & Pará & Altamira & Voss \& Emmons (1996) \\
\hline 9 & $01^{\circ} 08^{\prime} 24^{\prime \prime S}$ & $49^{\circ} 30^{\prime} 00^{\prime \prime} \mathrm{W}$ & Pará & Ilha de Marajó & Marques-Aguiar et al. (2002) \\
\hline 10 & $00^{\circ} 40^{\prime} 48^{\prime \prime} \mathrm{N}$ & $51^{\circ} 25^{\prime} 48^{\prime \prime} \mathrm{W}$ & Amapá & Colonia Agrícola de Matapi & Peracchi et al. (1984) \\
\hline 11 & $05^{\circ} 05^{\prime} 24^{\prime \prime} \mathrm{S}$ & $42^{\circ} 47^{\prime} 60^{\prime \prime} \mathrm{W}$ & Piauí & BR316, KM18, Teresina & Mares et al. (1981) \\
\hline 12 & $07^{\circ} 22^{\prime} 48^{\prime \prime S}$ & $40^{\circ} 12^{\prime} 36^{\prime \prime} \mathrm{W}$ & Ceará & Chapada do Araripe & Novaes \& Laurindo (2014) \\
\hline 13 & $07^{\circ} 29^{\prime} 24^{\prime \prime S}$ & $39^{\circ} 43^{\prime} 48^{\prime \prime} \mathrm{W}$ & Pernambuco & Exu & Rocha et al. (2011) \\
\hline $14^{*}$ & $07^{\circ} 10^{\prime} 12^{\prime \prime} \mathrm{S}$ & $34^{\circ} 49^{\prime} 12^{\prime \prime} \mathrm{W}$ & Paraíba & $\begin{array}{l}\text { Horto Florestal Municipal } \\
\text { Cidade Verde, João Pessoa }\end{array}$ & This study \\
\hline 15 & $09^{\circ} 57^{\prime} 36^{\prime \prime S}$ & $37^{\circ} 51^{\prime} 36^{\prime \prime} \mathrm{W}$ & Sergipe & Serra da Guia, Poço Redondo & Rocha et al. (2011) \\
\hline 16 & $10^{\circ} 52^{\prime} 35 " \mathrm{~S}$ & $38^{\circ} 01^{\prime} 10^{\prime \prime} \mathrm{W}$ & Sergipe & $\begin{array}{l}\text { Serra dos Macacos, Tobias } \\
\text { Barreto }\end{array}$ & Soares et al. (2018) \\
\hline 17 & $19^{\circ} 08^{\prime} 60^{\prime \prime S}$ & $40^{\circ} 03^{\prime} 36^{\prime \prime} \mathrm{W}$ & $\begin{array}{l}\text { Espírito } \\
\text { Santo }\end{array}$ & $\begin{array}{l}\text { Reserva Natural do Vale, } \\
\text { Linhares }\end{array}$ & Peracchi et al. (2011) \\
\hline 18 & $22^{\circ} 58^{\prime} 48^{\prime \prime S}$ & $43^{\circ} 21^{\prime} 36^{\prime \prime} \mathrm{W}$ & $\begin{array}{l}\text { Rio de } \\
\text { Janeiro }\end{array}$ & $\begin{array}{l}\text { Parque Arruda Câmara, Rio } \\
\text { de Janeiro }\end{array}$ & Nogueira et al. (2003) \\
\hline 19 & $22^{\circ} 57^{\prime} 36^{\prime \prime S}$ & $43^{\circ} 15^{\prime} 36^{\prime \prime} \mathrm{W}$ & $\begin{array}{l}\text { Rio de } \\
\text { Janeiro }\end{array}$ & $\begin{array}{l}\text { Jardim Botânico do Rio de } \\
\text { Janeiro }\end{array}$ & Nogueira et al. (2003) \\
\hline 20 & $19^{\circ} 28^{\prime} 48^{\prime \prime S}$ & $42^{\circ} 27^{\prime} 36^{\prime \prime} \mathrm{W}$ & Minas Gerais & $\begin{array}{l}\text { Parque Estadual do Rio Doce, } \\
\text { Marliéria }\end{array}$ & Nogueira et al. (2003) \\
\hline 21 & $15^{\circ} 15^{\prime} 00^{\prime \prime S}$ & $43^{\circ} 51^{\prime} 00^{\prime \prime} \mathrm{W}$ & Minas Gerais & Morro Solto, Jaíba & Nogueira et al. (2003) \\
\hline 22 & $14^{\circ} 39^{\prime} 00^{\prime S} \mathrm{~S}$ & $52^{\circ} 19^{\prime} 48^{\prime \prime W}$ & Mato Grosso & Nova Xavantina & Silva \& Anacleto (2011) \\
\hline 23 & $12^{\circ} 29^{\prime} 24^{\prime \prime S}$ & $51^{\circ} 27^{\prime} 36^{\prime \prime} \mathrm{W}$ & Mato Grosso & Serra do Roncador & Pine et al. (1970) \\
\hline
\end{tabular}




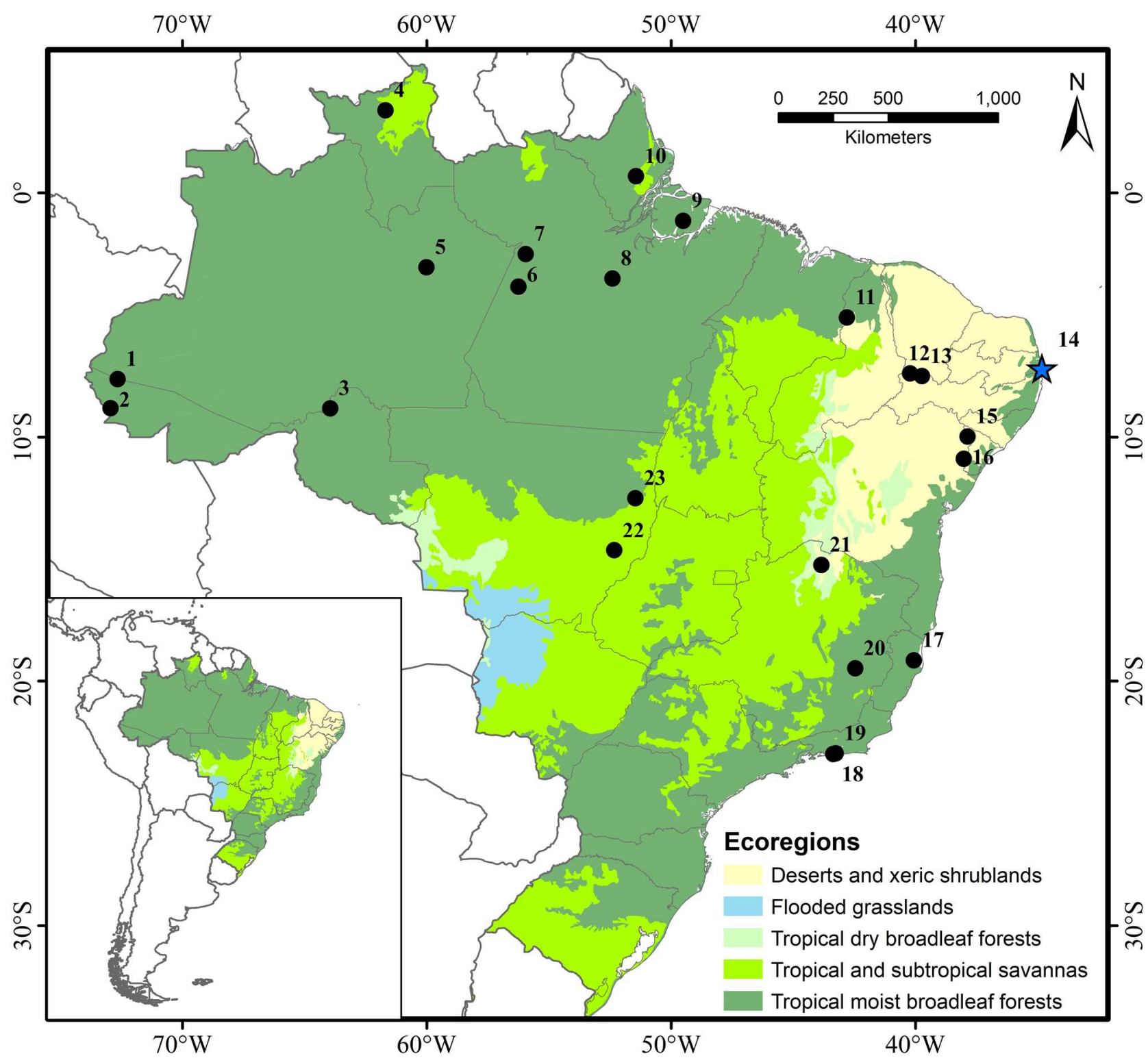

Figure 1. Geographic distribution of Uroderma magnirostrum (Chiroptera: Phyllostomidae) in Brazil. Star: new record in the state of Paraiba, Northeast of Brazil. Black circles: previous records. The numbers correspond to the records indicated in the Table 1.

one of the most threatened areas of tropical forest in the world (ca. $12 \%$ left and $1 \%$ legally protected), located north of the São Francisco River (Ribeiro et al. 2009). Our specimen was captured during a bat survey carried out in five Atlantic Forest fragments and in residential areas within the Metropolitan Region of João Pessoa (MRJP), state of Paraíba, Brazil (Figure 1). Total sampling effort was 55,580 $\mathrm{m}^{2} . \mathrm{h}, 10,500 \mathrm{~m}^{2} . \mathrm{h}$ for each forest fragment and $3,080 \mathrm{~m}^{2} . \mathrm{h}$ for residential areas, calculated following Straube \& Bianconi (2002). The $U$. magnirostrum specimen was captured in the Horto Florestal Municipal Cidade Verde (HFCV; $07^{\circ} 10^{\prime} 21.1^{\prime \prime S}, 34^{\circ} 49^{\prime} 23.2^{\prime \prime} \mathrm{W}$, datum WGS 84), an Atlantic Forest fragment with ca. 22 ha surrounded by an urban matrix. Local vegetation is made up by a secondary-growth semi-deciduous Atlantic Forest and Northeastern Tabuleiro, which is a savanna-like area common to coastal ecosystems, mainly characterized by the presence of smallsized trees and shrubs in sandy soils (OliveiraFilho \& Carvalho 1993). The climate is categorized as Tropical As, in Köppen's classification (Alvares et al. 2013), with an annual rainfall ranging from 1,500 to $1,700 \mathrm{~mm}$ and an average temperature from $22^{\circ} \mathrm{C}$ to $26^{\circ} \mathrm{C}$ (Feliciano \& Melo 2003). 
On April 24, 2015 a non-reproductive adult female of $U$. magnirostrum (Figure 2) was caught in the HFCV with a mist-net $(9 \mathrm{~m} \mathrm{x} 2.5 \mathrm{~m}, 20 \mathrm{~mm}$ mesh) set at ground level and opened during five consecutive hours after sunset $(17: 00 \mathrm{~h})$. This specimen was fixed in $10 \%$ formaldehyde and preserved in $70 \%$ ethanol, with subsequent extraction of the skull. External and cranial measurements (Table 2) were taken with digital caliper to the nearest $0.01 \mathrm{~mm}$ following Vizotto \& Taddei (1973). The specimen and its tissue samples were incorporated into the Collection of Mammals of the Federal University of Paraíba in the municipality of João Pessoa (UFPB 9823). Data collection was conducted under the authorization of the Chico Mendes Institute for Biodiversity Conservation (SISBIO license number: 45168-3) and animal procedures were approved by the Ethics Committee on Animal Use of the Federal University of Paraíba (CEUA/UFPB number 027/2016).
The specimen was identified by the presence of all four lower incisors in contact with each other and distinctly bifid and parallel upper internal incisors, features that distinguishes the genus Uroderma from other stenodermatines (Gardner 2007). However, in our specimen the upper incisors are separated by greater gaps and the lateral incisors are more reduced in size, in comparison with specimens illustrated in Rocha et al. (2011) and Mantilla-Meluk (2014). Also, our specimen presents the outermost of the ear pinna brownish and its basal portion slightly yellowish, rather than concolor as described by Davis (1968) and Nogueira et al. (2003). Despite this, the specimen has all the diagnostic characters previously provided for U. magnirostrum (Davis 1968, Nogueira et al. 2003, Gardner 2007, Rocha et al. 2011, Mantilla-Meluk 2014), such as narrow facial stripes which are in accordance with the less developed or prominent pattern described in the literature, pale-brownish fur color, borders of the

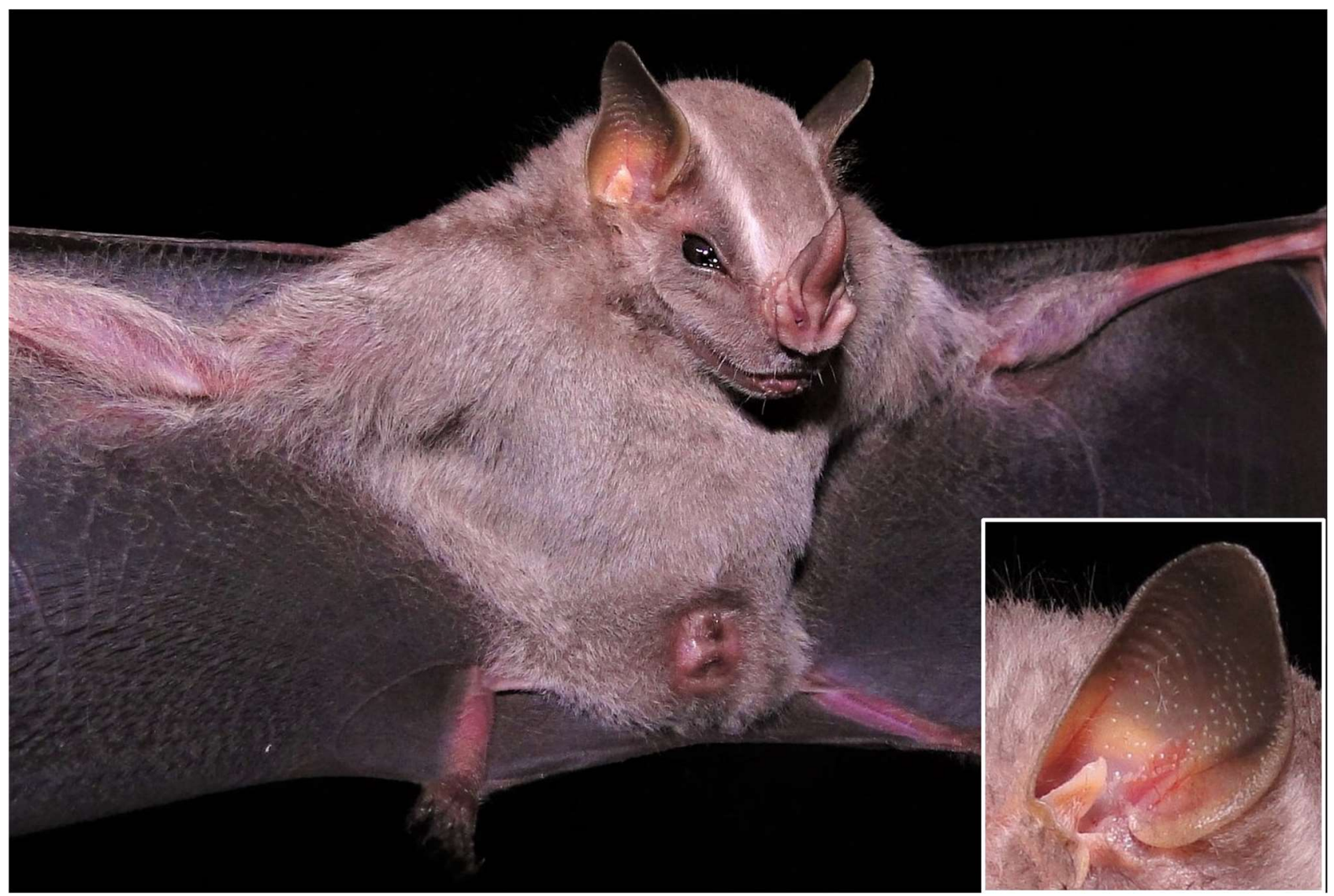

Figure 2. Adult female of Uroderma magnirostrum (Chiroptera: Phyllostomidae) from the municipality of João Pessoa, state of Paraíba, Brazil (UFPB 9823). The insert on the bottom right highlights the lack of a distinctive whitish or yellowish edge on the ear and its naked border. Photo: Hannah Nunes. 
Table 2. Measurements (in millimeters) and body mass (in grams) of Uroderma magnirostrum (Chiroptera: Phyllostomidae) specimens from Northeastern Brazil reported in the present study from the state of Paraíba and its closest records in the state of Sergipe (Rocha et al. 2011).

\begin{tabular}{|c|c|c|}
\hline Measurements & $\begin{array}{l}\text { Present study } \\
\text { ( }+ \text { UFPB 9823) }\end{array}$ & $\begin{array}{l}\text { Rocha et al. } 2011 \\
\qquad(10 ; 1)\end{array}$ \\
\hline Body mass & 19.00 & - \\
\hline Body length & 62.00 & - \\
\hline Hind foot length without claws & 8.00 & - \\
\hline Hind foot length with claws & 10.00 & \\
\hline Ear length & 14.00 & - \\
\hline Forearm length & 40.00 & - \\
\hline Greatest length of skull & 22.68 & $22.84-23.30$ \\
\hline Condylobasal length & 21.48 & $21.15-21.59$ \\
\hline Mastoid breadth & 10.80 & $10.75-10.92$ \\
\hline Zygomatic breadth & - & 12.52 \\
\hline Breadth of braincase & 9.23 & $9.23-9.66$ \\
\hline Postorbital constriction & 5.82 & $5.64-5.86$ \\
\hline Breadth across upper canines & 5.08 & $5.20-5.31$ \\
\hline Breadth across upper molars & 8.74 & $8.66-9.01$ \\
\hline Length of maxillary toothrow & 8.06 & $7.26-8.30$ \\
\hline Length of mandible & 15.74 & $15.04-15.54$ \\
\hline
\end{tabular}

ears naked and lacking a distinctive whitish or yellowish edges (Figure 2), skull with a flattened dorsal profile, a deep rostrum, and a wide nasal septum with a mesethmoid laterally expanded forming a shield-like structure (Figure 3 ).

The present record expands the species known distribution towards the Northeast by $450 \mathrm{~km}$ from the nearest existing record in the semi-arid Caatinga biome of the state of Sergipe (Rocha et al. 2011). Rocha et al. (2011) suggested that $U$. magnirostrum and $U$. bilobatum exhibit a disjunct distribution in the Northeastern region of Brazil, the former inhabiting only the semi-arid Caatinga and the latter the Atlantic Forest. However, our present record in the Atlantic Forest indicates that this expected previous scenario was probably a reflection of lack of studies than a true tolerance or preference for specific habitats by Uroderma magnirostrum. In fact, both species are also sympatric in Northeast of Brazil, as in great part of their South America distribution (Davis 1968).

Considering this new record, U. magnirostrum has been reported in 23 localities from 15 Brazilian states (Table 1). Despite the wide distribution, $U$. magnirostrum seems to be a locally rare species as suggested previously by Nogueira et al. (2003) and Rocha et al. (2011). In the present study, although the substantial sampling effort carried out (over 3,400 individuals captured in the MRJP), we captured only one individual in a single locality.

Based on our record and the fact that $U$. magnirostrum was already reported in other urban forest fragments in Brazil (e.g., Nunes et al. 2017), forested areas in urbanized landscapes appear to play a significant role in the maintenance of this species. In spite of the environmental and social importance of the HFCV, soon after the completion of our fieldwork, a relevant part of this studied area was deforested in order to construct houses by the Paraíba State Government. The impact of urbanization on the associated bat fauna is still poorly understood, but it is important to highlight that Atlantic Forest fragments within cities are known to provide refuge for bats that probably are less prone to explore the urban matrix (Araújo \& Bernard 2015).

The bat fauna from Paraíba has received increasing research attention in the last few years. Since the study of Feijó \& Langguth (2011), which compiled records for 53 bat species in this state, 


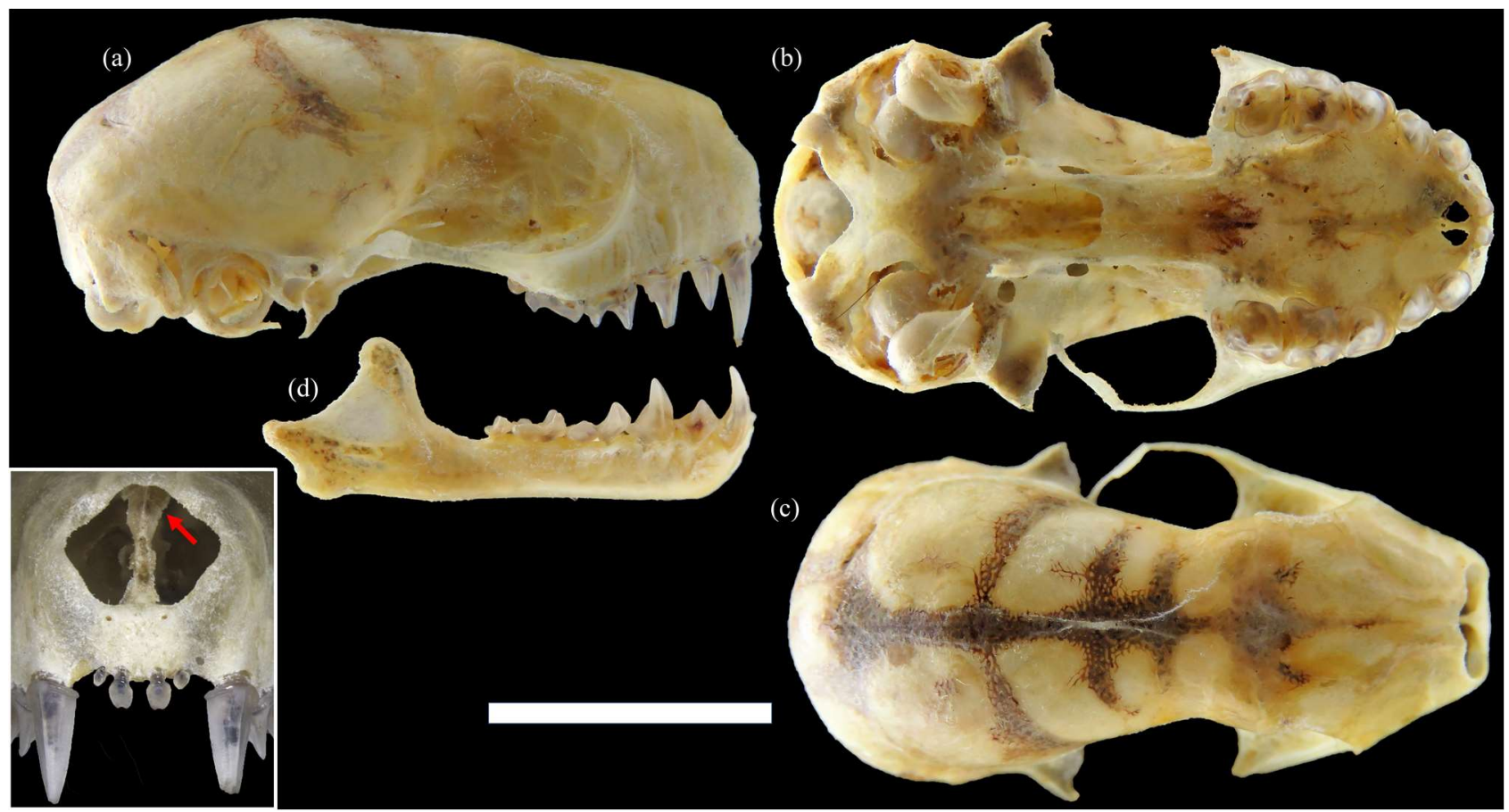

Figure 3. Lateral (a), ventral (b), and dorsal (c) views of the skull, and lateral view of the mandible (d) of Uroderma magnirostrum (Chiroptera: Phyllostomidae; UFPB 9823) from the state of Paraíba, Brazil. The insert on the bottom left shows the mesethmoid bone (indicated by the arrow) as well as the parallel and bilobate inner upper incisors (Scale bar $=10 \mathrm{~mm}$ ).

eight new species were added to the list, including the description of Histiotus diaphanopterus Feijó, Rocha \& Althoff, 2015 (Chiroptera: Vespertilionidae) (see Ferreira et al. 2013, Nunes et al. 2013, Leal et al. 2014, Feijó et al. 2015, Vilar et al. 2015, Zeppelini et al. 2016, 2017, Rocha et al. 2017). These new occurrences aforementioned were mainly a result of bat surveys in unexplored sites using diversified capture techniques, such as canopy mist-nets. Our record of $U$. magnirostrum updated the bat list of the state of Paraíba to 62 species. However, so far, only two studies were conducted in urban areas in this Brazilian state (Percequillo et al. 2007; present study). We therefore emphasize the need for future studies to take into account bats in urbanized environments to improve the knowledge of the regional bat fauna and the effects of urban expansion on these species.

\section{ACKNOWLEDGEMENTS}

We are thankful to the Military Police of Paraíba and the Center for Environmental Surveillance and Zoonoses in field assistance. We are also grateful to the students of the Department of Systematics and Ecology for their help during fieldwork. A doctoral grant was provided by Coordenação de Aperfeiçoamento de Pessoal de Nível Superior (CAPES) to H.N and a PNPD/CAPES fellowship to PAR and FLR. This study was funded by the Programa Pesquisa para o SUS, Edital 01/2013 - PPSUS/FAPESQ/MS/CNPq (grant number EFP_00008705).

\section{REFERENCES}

Alvares, C. A., Stape, J. L., Sentelhas, P. C., \& Gonçalves, J. L. M. 2014. Köppen's climate classification map for Brazil. Meteorologische Zeitschrift, 22(6), 711-728. DOI: 10.1127/09412948/2013/0507

Araújo, M. L. V. S., \& Bernard, E. 2015. Green remnants are hotspots for bat activity in a large Brazilian urban area. Urban Ecosystems, 19(1), 287-296. DOI: $10.1007 / \mathrm{s} 11252-015-0487-\mathrm{Z}$

Bernard, E., \& Fenton, M. B. 2002. Species diversity of bats (Chiroptera: Mammalia) in forest fragments, primary forests and savannas in Central Amazonia, Brazil. Canadian Journal of Zoology, 
80(6), 1124-1140. DOI: 10.1139/z02-094

Bernard, E., Tavares, V. C., \& Sampaio, E. 2011. Updated compilation of bat species (Chiroptera) for the Brazilian Amazonia. Biota Neotropica, 11(1), 35-46. DOI: 10.1590/S1676-06032011000 100003

Davis, W. B. 1968. Review of the genus Uroderma (Chiroptera). Journal of Mammalogy, 49(4), 676-698. DOI: $10.2307 / 1378728$

Feliciano, M. L. M., \& Melo, R. B. 2003. Atlas do estado da Paraíba: informação para gestão do patrimônio natural (mapas). 1 ed. João Pessoa: SEPLAN/IDEME.

Feijó, J. A., \& Langguth, A. 2011. Lista dos quirópteros da Paraíba, com 25 novos registros. Chiroptera Neotropical, 17(2), 1055-1062.

Feijó, A., Rocha, P. A., \& Althoff, S. L. 2015. New species of Histiotus (Chiroptera: Vespertilionidae) from northeastern Brazil. Zootaxa, 4048(3), 412-427. DOI: 10.11646/zootaxa.4048.3.4

Ferreira, A. P., Melo, D. C., \& Ribeiro, A. 2013. Diclidurus albus Wied-Neuwied, 1820 (Chiroptera: Emballonuridae): first record of the species in the state of Paraíba, Brazil. Check List, 9(4), 793-796. DOI: 10.15560/9.4.793

Gardner, A. L. 2007. Mammals of South America, Volume 1, marsupials, xenarthrans, shrews, and bats. Chicago: University of Chicago Press: p. 669.

Handley Jr., C. O. 1976. Mammals of the Smithsonian Venezuelan project. Brigham Young University Science Bulletin, Biological Series, Provo, 20(5), 1-91. DOI: 10.5962/bhl.part. 5667

Leal, E. S. B., Gomes-Silva, F. F., Lira, T. C., Prado Neto, J. G., \& Passos Filho, P. B. 2014. Occurrence of Furipterus horrens (F. Cuvier, 1828) (Chiroptera: Furipteridae) in the state of Paraíba and an update of the distribution of the species in Brazil. Chiroptera Neotropical, 20(20), 1280-1287.

Mantilla-Meluk, H. 2014. Defining species and species boundaries in Uroderma (Chiroptera: Phyllostomidae) with a description of a new species. Occasional Papers, Museum of Texas Tech University, 325,1-25.

Mares, M. A., Willig, M. R., Streilein, K. E., \& Lacher, T. E. 1981. The mammals of northeastern Brazil: a preliminary assessment. Annals of the Carnegie Museum, 50, 81-137.
Marques-Aguiar, S. A., Melo, C. C. S., Aguiar, G. F. S., \& Queiróz, J. A. L. 2002. Levantamento preliminar da mastofauna da região de AnajásMuaná, Ilha de Marajó, Pará, Brasil. Revista Brasileira de Zoologia, 19(3), 841-854.

Nogueira, M. R., Tavares, V. C., \& Peracchi, A. L. 2003. New records of Uroderma magnirostrum Davis, 1968 (Mammalia, Chiroptera) from southeastern Brazil, with comments on its natural history. Revista Brasileira de Zoologia, 20(4), 691-697. DOI: 10.1590/S0101-8175200300 0400023

Novaes, R. L. M., \& Laurindo, R. S. 2014. Morcegos da Chapada do Araripe, nordeste do Brasil. Papéis Avulsos de Zoologia (São Paulo), 54(22), 315-328. DOI: 10.1590/0031-1049.2014.54.22

Nunes, H., Rocha, F. L., \& Cordeiro-Estrela, P. 2017. Bats in urban areas of Brazil: roosts, food resources and parasites in disturbed environments. Urban Ecosystems, 20(4), 953-969. DOI: 10.1007/s11252-016-0632-3

Nunes, H., Feijó, J. A., Beltrão, M., Lopez, L. C. S., \& Fracasso, M. P. A. 2013. First and easternmost record of Molossops temminckii (Burmeister, 1854) for the State of Paraíba, Brazil. Check List, 9(2), 436-439. DOI: 10.15560/9.2.436

Oliveira-Filho, A. T., \& Carvalho, D. A. 1993. Florística e fisionomia da vegetação no extremo norte do litoral da Paraíba. Revista Brasileira de Botânica, 16, 115-130.

Oprea, M., Mendes, P., Vieira, T. B., \& Ditchfield, A. D. 2009. Do wooded streets provide connectivity for bats in an urban landscape? Biodiversity Conservation, 18(9), 2361-2371. DOI: $10.1007 / \mathrm{s}$ 10531-009-9593-7

Peracchi, A. L., Nogueira, M. R., \& Lima, I. P. 2011. Novos achegos à lista dos quirópteros do município de Linhares, estado do Espírito Santo sudeste do Brasil (Mammalia, Chiroptera). Chiroptera Neotropical, 17(1), 842-852.

Peracchi, A. L., Raimundo, S. D. L., \& Tannure, A. M. 1984. Quirópteros do território Federal do Amapá, Brasil (Mammalia, Chiroptera). Arquivos da Universidade Federal Rural do Rio de Janeiro, Seropédica, 7(2), 89-100.

Percequillo, A., Santos, K., Campos, B. Santos, R. Toledo, G., \& Langguth, A. 2007. Mamíferos dos remanescentes florestais de João Pessoa, Paraíba. Biologia Geral e Experimental, 7(2), 1731. 
Pine, R. H., Bishop, I. R., \& Jackson, R. L. 1970. Preliminary list of mammals of the Xavantina/Cachimbo expedition (Central Brazil). Transactions of the Royal Society of Tropical Medicine and Hygiene, 64(5), 668-670.

Reis, N. R., \& Peracchi, A. L. 1987. Quirópteros da região de Manaus, Amazonas, Brasil (Mammalia, Chiroptera). Boletim do Museu Paraense Emílio Goeldi, Nova Série, Zoologia, 3(2), 161-182.

Reis, N. R., \& Schubart, H. O. R. 1979. Notas preliminares sobre os morcegos do Parque Nacional da Amazonia (Medio Tapajos). Acta Amazonica, 9(3), 507-515. DOI: 10.1590/180943921979093507

Ribeiro, M. C., Metzger, J. P., Martensen, A. C., Ponzoni, F. J, \& Hirota, M. M. 2009. The Brazilian Atlantic Forest: how much is left, and how is the remaining forest distributed? Implications for conservation. Biological Conservation, 142(6), 1141-1153. DOI: 10.1016/j.bio con.2009.02.021

Rocha, P. A., Feijó, J. A., Ruiz-Esparza, J., \& Ferrari, S. F. 2011. Uroderma magnirostrum Davis, 1968 (Chiroptera: Phyllostomidae): first record from the state of Sergipe, northeastern Brazil. Check List, 7(6), 886-888. DOI: 10.15560/7.6.886

Rocha, P. A., Soares, F. A. M., Dias, D., Mikalauskas, J. S., Feijó, A., Vilar, E. M., \& Daher, M. R. M. 2017. New records of Micronycteris schmidtorum Sanborn, 1935 (Phyllostomidae, Chiroptera) for northeastern Brazil. Mastozoología Neotropical, 24(2), 475-482.

Silva, J. M. C., \& Casteleti, C. H. M. 2003. Status of the biodiversity of the Atlantic Forest of Brazil. In: C. Galindo-Leal \& I. G. Câmara (Eds.), The Atlantic Forest of South America: biodiversity status, threats, and outlook. pp. 43-59. Washington: CABS and Island Press.

Silva, S.G., \& Anacleto, T. C. S. 2011. Diversidade de morcegos entre áreas com diferente grau de alteração na área urbana do município de Nova Xavantina, MT. Chiroptera Neotropical, 17(2), 1003-1012.

Soares, F., Rocha, P. A., Bocchiglieri, A., \& Ferrari, S. F. 2018. Structure of a bat community in the xerophytic Caatinga of the state of Sergipe, Northeastern Brazil. Mammalia, apo, DOI:10. 1515/mammalia-2018-0029.

Straube, F. C., \& Bianconi, G. V. 2002. Sobre a grandeza e a unidade utilizada para estimar esforço de captura com utilização de captura com utilização de redes de neblina. Chiroptera Neotropical, 8(1-2),150-152.

Taddei, V. A., Rezende, I. M., \& Camora, D. 1990. Notas sobre uma coleção de morcegos de Cruzeiro do Sul, rio Juruá, Estado do Acre (Mammalia, Chiroptera). Boletim do Museu Paraense Emílio Goeldi, Nova Série Zoologia, 6(1), 75-88.

Taddei, V. A., \& Reis, N. R. 1980. Notas sobre alguns morcegos da ilha de Maracá, Território Federal de Roraima (Mammalia, Chiroptera). Acta Amazonica, 10(2), 75-88. DOI: 10.1590/18 09-43921980102363

Tavares, V. C., Nobre, C. C., Palmuti, C. F. S., Nogueira, E. P. P., Gomes, J. D., Marcos, M. H., Silva, R. F., Farias, S. G., \& Bobrowiec, P. E. D. 2017. The bat fauna from southwestern Brazil and its affinities with the fauna of western Amazon. Acta Chiropterologica, 19(1), 93-106. 10.3161/15081109ACC2017.19.1.007

Vilar, E. M., Nunes, H., Nascimento, J. L., \& Estrela, P. C. 2015. Distribution extension of Ametrida centurio Gray, 1847 (Chiroptera, Phyllostomidae): first record in the Brazilian Atlantic Forest. Check List, 11(1), 1-5. DOI: 10.15560/1 1.1 .1503

Vizotto, L. D., \& Taddei, V. A. 1973. Chave para determinação de quirópteros brasileiros. São José do Rio Preto: Editora da UNESP, 72 p.

Voss, R. S., \& Emmons, L. H. 1996. Mammalian diversity in Neotropical lowland rainforests: a preliminary assessment. Bulletin of the American Museum of Natural History, 230, 1-115

Zeppelini, C. G., Jerônimo, I., Da Costa Rêgo, K. M., Fracasso, M. P. A., Lopez, L. C. S. 2016. Bat assemblage of Guaribas Biological Reserve, an Atlantic Forest conservation unit in Northeastern Brazil: results of a two-stage long-term survey. Acta Scientiarum, 38(3), 365-369. DOI: 10.4025/ actascibiolsci.v38i3.31248

Zeppelini, C. G., Rêgo, K. M. C., \& Lopez, L. C. S. 2017. Bats in settlements from an Atlantic Forest area in northeastern Brazil. Papéis Avulsos de Zoologia, 57(31), 405-411. DOI: 0.11606/0031-10 49.2017.57.31

Submitted: 08 March 2018 Accepted: 10 July 2018 Associate Editor: Ana C. Delciellos 